\title{
From Bacteria to Fish: Ecological Consequences of Seasonal Hypoxia in a Great Lakes Estuary
}

\author{
Anthony D. Weinke* and Bopaiah A. Biddanda
}

Annis Water Resources Institute, Grand Valley State University, 740 W. Shoreline Dr., Muskegon, Michigan 49441, USA

\begin{abstract}
The occurrence of bottom-water hypoxia is increasing in bodies of water around the world. Hypoxia is of concern due to the way it negatively impacts lakes and estuaries at the whole ecosystem level. During 2015, we examined the influence of hypoxia on the Muskegon Lake ecosystem by collecting surface- and bottom-water nutrient samples, bacterial abundance counts, benthic fish community information, and performing profiles of chlorophyll and phycocyanin as proxies for phytoplankton and cyanobacterial growth, respectively. Several significant changes occurred in the bottom waters of the Muskegon Lake ecosystem as a result of hypoxia. Lake-wide concentrations of soluble reactive phosphorus (SRP) and total phosphorus increased with decreasing dissolved oxygen (DO). Bacterial abundance was significantly lower when DO was less than $2.2 \mathrm{mg} \mathrm{L}^{-1}$. Whereas there were no drastic changes in surface chlorophyll $a$
\end{abstract}

Received 30 January 2017; accepted 20 May 2017;

published online 8 June 2017

Electronic supplementary material: The online version of this article (doi:10.1007/s10021-017-0160-x) contains supplementary material, which is available to authorized users.

Author Contributions AW conceived and designed the study, performed research, analysis of samples, and wrote the paper. BB designed the study, performed research, analysis of samples, and co-wrote the paper.

*Corresponding author; e-mail: weinkean@gvsu.edu concentration through the season, phycocyanin increased threefold during and following a series of major wind-mixing events. Phycocyanin remained elevated for over 1.5 months despite several strong wind events, suggesting that high SRP concentrations in the bottom waters may have mixed into the surface waters, sustaining the bloom. The fish assemblage in the hypolimnion also changed in association with hypoxia. Overall fish abundance, number of species, and maximum length all decreased in catch as a function of bottom DO concentrations. The link between hypoxia and wind events appears to serve as a positive feedback loop by continuing internal loading and cyanobacterial blooms in the lake, while simultaneously eroding habitat quality for benthic fish.

Key words: hypoxia; fish; nutrients; bacteria; cyanobacteria; internal loading.

\section{INTRODUCTION}

Aquatic hypoxia is expanding its extent around the globe, which has many consequences for the ecosystems it affects (Diaz 2001). Although most of the attention is on marine systems, where there are estimated to be over 400 hypoxic zones globally, freshwater hypoxia is increasing as well (Diaz and Rosenberg 2008; Jenny and others 2016). Hypoxia is thought to be natural in many systems as a result of thermal stratification and excess organic matter decomposition (Zhou and others 2015; Jenny and others 2016). However, in a study of 365 lakes 
distributed around the world, 71 developed hypoxia within the last 300 years (Jenny and others 2016). Many studies attribute the development of hypoxia within freshwater systems to eutrophication (Diaz 2001; Scavia and others 2014; Jenny and others 2016), but global climate change also is suspected to play a role in increasing the strength of stratification and bacterial metabolic rates while decreasing dissolved oxygen (DO) solubility (Sahoo and others 2011; Dokulil and others 2013).

An intensely studied consequence of hypoxia is the effect it has on fish due to their economic and food importance. At the cellular level, hypoxia has been shown to be an endocrine disruptor, impairing the ability for fish to reproduce, as well as a teratogen, leading to malformed embryos ( $\mathrm{Wu}$ and others 2003; Shang and Wu 2004). Although many laboratory studies indicate decreased consumption and growth as a result of hypoxia exposure, some indicate that these effects may not be seen in the wild because fish have the ability to detect and avoid hypoxia (Burleson and others 2001; Roberts and others 2011; Vanderplancke and others 2015). However, numerous studies also show the impacts of hypoxia on fish because they must move to higher oxygenated areas that may not be preferred habitat (Eby and others 2005; Ludsin and others 2009; Roberts and others 2009; Brown and others 2015; Kraus and others 2015). Not only does hypoxia cause fish to move, but zooplankton and prey fish may be forced to move. Hypoxia-intolerant species must move to shallower water, to the same areas that the larger fish have also been restricted, which increases trophic interactions to a perhaps unnatural level (Eby and Crowder 2002). Those that are fairly tolerant of hypoxia can actually use it to their advantage, swimming down into water that larger fish are unwilling to venture into (Ludsin and others 2009; Larsson and Lampert 2011). This, of course, comes at the cost of living in hypoxia (Larsson and Lampert 2011; Goto and others 2012). DO is one of the major factors that shapes fish assemblages (Killgore and Hoover 2001; Eby and Crowder 2002; Bhagat and Ruetz 201 1; Altenritter and others 2013).

Another concern with bottom-water hypoxia is the internal regeneration or loading of nutrients. External loads of phosphorus are the primary cause of eutrophication of freshwater systems, which helps initiate algal blooms and subsequent hypoxia (Scavia and others 2014). In efforts to reverse eutrophication, watershed managers often point to reducing phosphorus loads to lakes to improve water quality; however, systems can maintain their eutrophic status through hypoxia-mediated inter- nal loading (Nürnberg and others 2013). Phosphorus is normally oxidized and bound to metals under oxic conditions, but under low-oxygen conditions, the system becomes reducing and releases bioavailable forms into the water column (Smith and others 2011). Once concentrated in the bottom waters, the sediment-derived nutrients are typically isolated until the fall turnover. However, during extreme wind events, these nutrients may be entrained into the surface waters (Jennings and others 2012; Crockford and others 2014). Episodic influxes of nutrients to surface waters may be a mechanism for stimulating algal blooms, especially cyanobacteria, during the late summer period where water temperatures are warmest, stratification is strongest, and hypoxia is the most severe of the season (Crockford and others 2014). Algal blooms as a result of these nutrient supplies could potentially sustain themselves for weeks (Kamarainen and others 2009).

The main objective of this study was to detect and evaluate changes that occurred in Muskegon Lake during 2015 as a result of bottom-water hypoxia. We addressed this objective by: (1) quantifying surface and bottom nutrient concentrations of four locations in Muskegon Lake to find evidence of nutrient regeneration in bottom waters and episodic transport to surface waters, (2) measuring bacterial abundance at the surface and bottom for changes in overall abundance correlated with hypoxia, (3) identifying what benthic fish species are present during hypoxia and in what abundances, (4) tracking chlorophyll $a$ and phycocyanin pigment measurements in the surface waters to correlate blooms with major episodic wind events. We hoped to understand the concurrent changes that take place in Muskegon Lake at multiple levels within the ecosystem as a result of hypoxia, to better inform us as to what occurs in similar lakes that experience hypoxia.

\section{Methods}

\section{Study Site}

Muskegon Lake is located midway up Michigan's western coast and is one of many drowned rivermouth lakes that naturally occur along this specific coast (Figure 1). Its primary inflow is on the West side from the Muskegon River watershed, which is the second largest in Michigan $\left(7302 \mathrm{~km}^{2}\right.$; Marko and others 2013). It has additional smaller tributaries of Ruddiman Creek to the south and Bear Lake to the North. The mean hydraulic residence time changes seasonally (14-70 days) and with the 


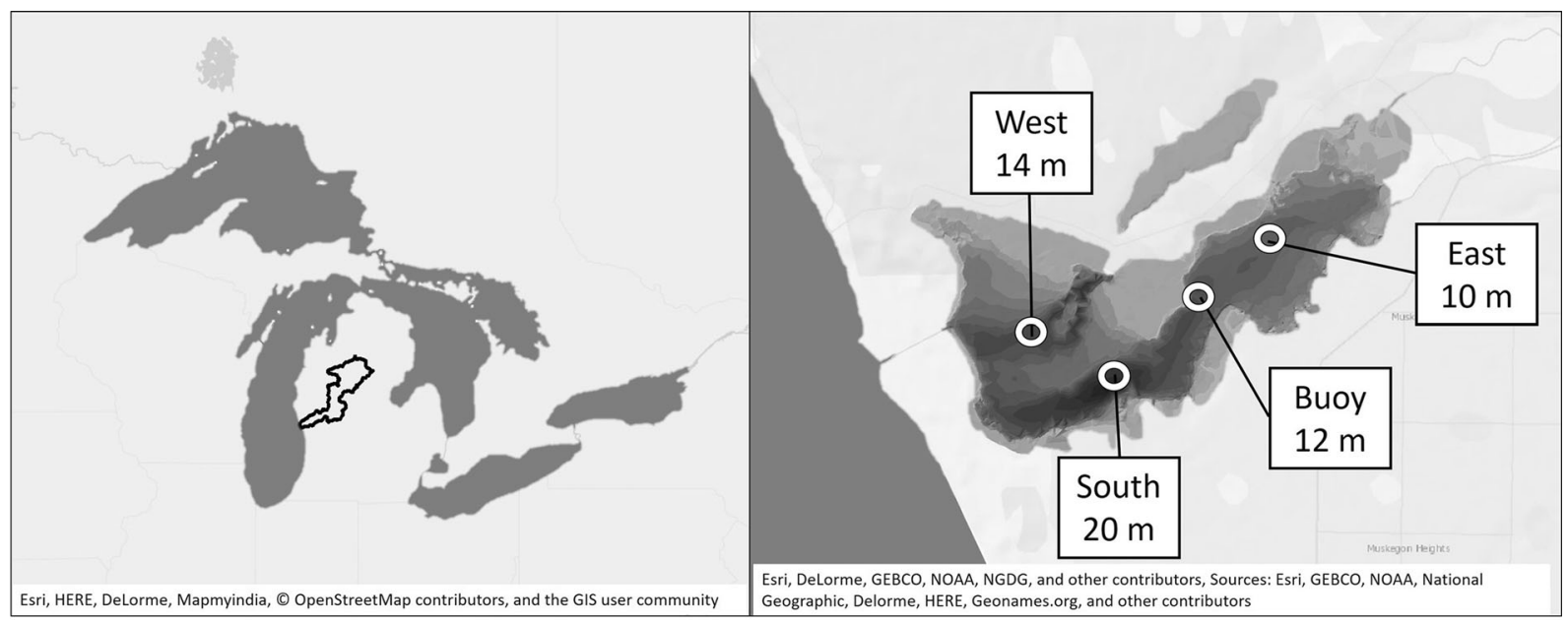

Figure 1. (Left) Map of the Great Lakes region with black outline of the Muskegon River watershed that leads into Muskegon Lake, Michigan. (Right) Bathymetric map of Muskegon Lake, Michigan, with rings indicating the basin sampling locations with site name and approximate depths.

weather, and averages approximately 23 days (Freedman and others 1979; Marko and others 2013).

Sample locations (East, West, and South) in Muskegon Lake were purposefully chosen because they represented the center of the lake's three subbasins and were located away from any tributary inflows. The fourth location (Buoy) was selected because it is located near the middle of Muskegon Lake, and it is where a time-series observatory buoy is located. The Muskegon Lake Observatory buoy (MLO) has been collecting high-frequency, time-series water-quality data at multiple depths and above-surface meteorological data since 2011 (Biddanda and others, unpublished manuscript). More information on the buoy observatory can be found at www.gvsu.edu/buoy and in Vail and others (2015).

\section{Sample Collection and Water-Quality Profiles}

Monitoring was done at four sites in Muskegon Lake (East, Buoy, West, and South) and was visited biweekly in 2015 starting on May 6 and ending on November 4 (Figure 1). The sites were sampled in the morning hours between approximately 8 a.m. and 11 a.m. in order of East, Buoy, West, and then South. Order of sampling was not randomized in order to sample all four locations in the least time possible and avoid too much influence of changing time of day. At each site, a YSI Datasonde (Yellow Springs Instruments), equipped with temperature, DO, chlorophyll $a$, and phycocyanin sensors, was used to perform a profile of the water column. It was allowed to equilibrate as close to the surface as possible for $1 \mathrm{~min}$ and then lowered at a rate of roughly $1 \mathrm{~m} / \mathrm{min}$ to the previously measured depth using a drop rope and weight. DO was not calibrated each trip because these sondes are calibrated monthly.

\section{Nutrients}

At each site, water for nutrient analysis was gathered biweekly using a Van Dorn bottle from $1 \mathrm{~m}$ below the surface and $1 \mathrm{~m}$ above the sediment. Water was dispensed from the sampler into acidwashed Nalgene bottles. Bottles were kept on ice in a cooler until the return to the laboratory, where they were immediately transported to the in-house chemistry laboratory at the Annis Water Resources Institute, Muskegon, Michigan (AWRI). Samples were collected for soluble reactive phosphorus (SRP), total phosphorus (TP), ammonia $\left(\mathrm{NH}_{3}\right)$, and total Kjeldahl nitrogen (TKN). They were analyzed in-house at AWRI, according to EPA (1993) methods. Samples that were below the detection limit were assumed to be $50 \%$ of the detection limit $\left(\mathrm{SRP}=0.005 \mathrm{mg} \mathrm{L}^{-1}, \mathrm{NH}_{3}=0.01 \mathrm{mg} \mathrm{L}^{-1}\right)$.

For the four types of nutrients, statistical analyses were performed to assess the relationship between nutrient concentrations and DO while taking possible site heterogeneity into account. To define what concentrations of DO cause important increases or decreases in nutrient concentrations and what sites have higher or lower nutrients at certain ranges of DO, we used CART (categorical and regression tree) analysis. CART divides a dataset into two sections based on the maximum reduction in variance of the two groups. Then, each group is 
divided into two more groups if it results in another substantial reduction in variance. We "grew" our trees using nutrient concentrations as the dependent variable and DO and Site as independent variables. This analysis was performed with the "Tree" package in the statistical program R. Trees tend to overfit, dividing the dataset into too many separate groups. Trees were "pruned" to limit the number of end nodes or "leaves" that were relevant to the current study. If graphs of nutrient concentrations predicted by DO and CART analyses revealed differences between sites, linear regressions were performed on sets of similar sites using nutrient concentrations (transformed if necessary) as the dependent and DO as the independent variables.

\section{Bacteria}

Bacteria in $5 \mathrm{~mL}$ lake water samples were preserved with $2 \%$ formalin, and $1 \mathrm{~mL}$ subsamples were stained with acridine orange stain and filtered onto black $25-\mathrm{mm}(0.2-\mu \mathrm{m}$ pore size) polycarbonate Millipore filters. Prepared slides were frozen and stored in the freezer until enumeration. Bacterial enumeration was performed via standard epifluorescence microscopy at 1000x Magnification (Hobbie and others 1977; Dila and Biddanda 2015). The statistical analysis for bacterial abundance was performed in the same way as nutrient concentrations.

\section{Chlorophyll a and Phycocyanin}

To analyze the ability for major mixing events to initiate algal blooms, we compared near-surface chlorophyll and phycocyanin concentrations before and after the first major mixing event of the summer on $8 / 2 / 15$. Concentrations were measured by YSI 6025 chlorophyll $a$ (unit: $\mu \mathrm{g} \mathrm{L}^{-1}$ ) and YSI 6131 phycocyanin (unit: cells $\mathrm{mL}^{-1}$ ) sensors. Chlorophyll $a$ and phycocyanin from profiles were averaged for each site between 1 and $2 \mathrm{~m}$, which encompasses the maximum concentration ranges for the water column. The sites and dates were pooled for before and after $8 / 2 / 15$ and compared using a paired Wilcoxon test.

\section{Fish}

We collected fish using gill nets at the Buoy location. The fish were caught in two $38.1 \mathrm{~m}$ long by $1.8 \mathrm{~m}$ tall experimental gill nets, with 5 mesh sizes ranging from $2.54 \mathrm{~cm}$ up to $12.7 \mathrm{~cm}$ bar measure by increments of $2.54 \mathrm{~cm}$ (Sanders and others 2011; Altenritter and others 2013). Nets were de- ployed at approximately 8 a.m. and recovered $3 \mathrm{~h}$ later. Fish were identified to species and total length measured. Nets were placed on the bottom of the northeast and southwest sides of the MLO at a depth of approximately $12 \mathrm{~m}$. Nets were always deployed with the smallest mesh size facing North for consistency.

Linear regressions were used to investigate the relationship of fish abundance, number of species, and maximum length to the lowest DO concentration measured in the water column during the day of sampling. Normality was tested using a Shapiro-Wilk test. Abundance and richness were not normal, but were square-root-transformed and were then normally distributed. Maximum lengths were normal, and linear regressions were performed accordingly. Regressions were considered significant at $\alpha<0.05$.

\section{RESUlts \\ Hypoxia}

The weather conditions in Muskegon were fairly normal for temperature, with air temperatures being average to slightly below normal, and the spring of 2015 was preceded by a much colder than normal winter. There was a longer duration of high wind speeds from May 2015 to October 2015 compared to the other years that the MLO has been in operation, most notably May, August, and October. There was an above average amount of precipitation in the Muskegon area during the same time due to a few large precipitation events in June and September.

In 2015, mild (DO $<4 \mathrm{mg} \mathrm{L}^{-1}$ ) and severe $\left(\right.$ DO $<2 \mathrm{mg} \mathrm{L}^{-1}$ ) hypoxia were detected at all four sampling locations via biweekly profiles (Table 1). Mild hypoxia was consistently detected for months at a time in all four locations, with occasional detections of severe hypoxia. Severe hypoxia was only consistently detected at the South location. The persistence of even mild hypoxia is also illustrated by $11 \mathrm{~m}$ DO sensor data from the MLO (Figure 2). It shows the development of low DO conditions toward late June and early July before an intrusion of Lake Michigan water into the bottom of Muskegon Lake, which pushed the less dense hypoxic water upward in the water column (Figure 3). The intrusion of Lake Michigan water into the bottom of Muskegon Lake is characterized by a sudden decrease in temperature in the already cooler hypolimnion, increased bottom DO despite conditions conducive to hypoxia formation, and decreased bottom specific conductivity in the nor- 
Table 1. Detection of Mild and Severe Hypoxia During Biweekly DO Profiles at Four Sample Sites in Muskegon Lake in 2015

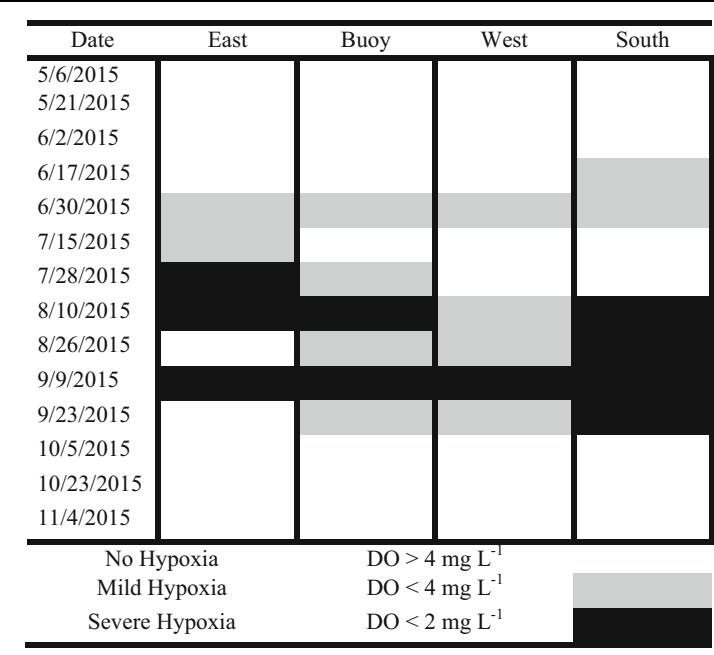

Color of boxes indicate whether or not hypoxia of any kind was detected anywhere in the water column on that date. White (normoxic) $=D O>4 \mathrm{mg} \mathrm{L}^{-1}$, gray (mild hypoxia) $=D O<4 \mathrm{mg} \mathrm{L}^{-1}$, black (severe hypoxia) $=D O<2 \mathrm{mg} \mathrm{L}^{-1}$.

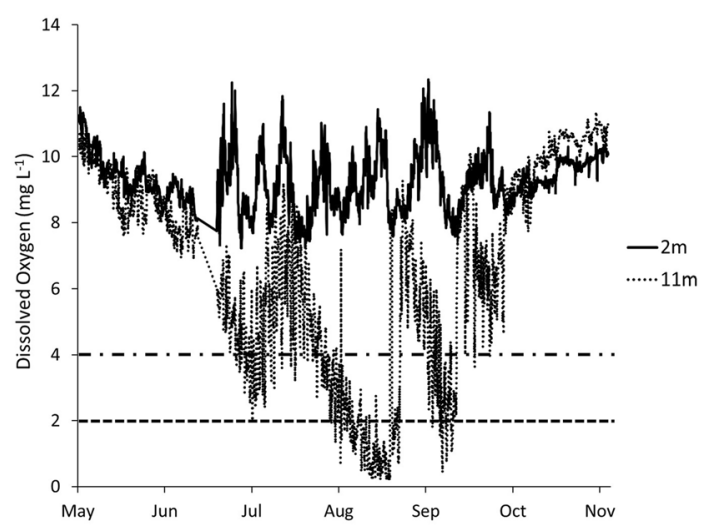

Figure 2. Hourly time-series dissolved oxygen data from the Muskegon Lake Observatory buoy 2-m (black solid) and $11-\mathrm{m}$ (black dots) sensors. Horizontal lines at $4 \mathrm{mg} \mathrm{L}^{-1}$ (black dashes and dots) and $2 \mathrm{mg} \mathrm{L}^{-1}$ (black dashes) represent thresholds for mild and severe hypoxia, respectively.

mally higher conductivity Muskegon Lake water, all of which were seen in this case. Despite these episodic intrusions of colder, oxygenated, and lower conductivity water from Lake Michigan, hypoxia quickly redeveloped in Muskegon Lake, reaching severe hypoxia by the end of July.

Although wind-driven mixing events are common on Muskegon Lake, three especially strong events occurred during August 2015 (Table 2), which significantly mixed the lake, and deepened the thermocline by several meters (Supplemental Figure 1). Normal mixing events during the summer do not typically affect the bottom waters; however, these events did (Figure 3 ). Wind speeds of approximately $10 \mathrm{~m} \mathrm{~s}^{-1}$ occurred and lasted for many consecutive hours, and sometimes days, at a time (Table 2). The first two events resulted in temporary mixing of the water column down to $11 \mathrm{~m}$ for a few hours. The third combined a severe wind-driven mixing event with a cold air front, which kept the epilimnion mixed down to 10-11 m in late August. This event relieved all hypoxia at the East site and some of the hypoxia at the Buoy site, relegating hypoxia to the bottom $1 \mathrm{~m}$ for several days afterward. Again, hypoxia quickly redeveloped into mid-September.

\section{Nutrients}

SRP showed the most drastic patterns in relation to seasonality and hypoxia. Surface concentrations remained mostly undetectable through the spring and summer until the fall overturn when concentrations increased to similar levels as the bottom waters (Supplemental Figure 2A). The bottom waters almost always had detectable concentrations of SRP; however, SRP was noticeably higher in the bottom waters during the summer months when hypoxia develops. The deeper sites, West and South, showed an uninterrupted increase in SRP following the Lake Michigan water intrusion event, whereas the shallower sites, East and Buoy, fell to undetectable concentrations of SRP following the August mixing events.

The regression tree for SRP revealed important groupings based on DO concentration as well as between sites (Figure 4A). The first bifurcation divided the entire dataset at $3.0 \mathrm{mg} \mathrm{L}^{-1} \mathrm{DO}$ with average concentrations of SRP $0.0302 \mathrm{mg} \mathrm{L}^{-1}$ below $3.0 \mathrm{mg} \mathrm{L}^{-1}$ DO compared to $0.0102 \mathrm{mg} \mathrm{L}^{-1} \mathrm{SRP}$ above. Of the remaining data points below $3.0 \mathrm{mg} \mathrm{L}^{-1}$ DO, the sites South and West combined had $2 x$ higher concentrations than East and Buoy. This same pattern occurred between 3.0 and $6.8 \mathrm{mg} \mathrm{L}^{-1}$ DO. All sites were of similar concentration above $6.8 \mathrm{mg} \mathrm{L}^{-1}$ DO. Overall, SRP was $4.25 \mathrm{x}$ higher below $3.0 \mathrm{mg} \mathrm{L}^{-1}$ DO than above $6.8 \mathrm{mg} \mathrm{L}^{-1}$ DO.

A graph of SRP predicted by DO revealed a Log relationship for both East/Buoy and West/South groups (Figure 4B), so we ran two separate linear regressions of natural log-transformed SRP concentrations predicted by DO. This revealed a significant inverse relationship for both groups East/Buoy $\left(p=0.0038, \quad r^{2}=0.28, \quad F_{1,26}=10.08\right.$ $(\mathrm{SRP})=-0.052 \pm 0.016(\mathrm{DO})-1.76)$ and West/ 

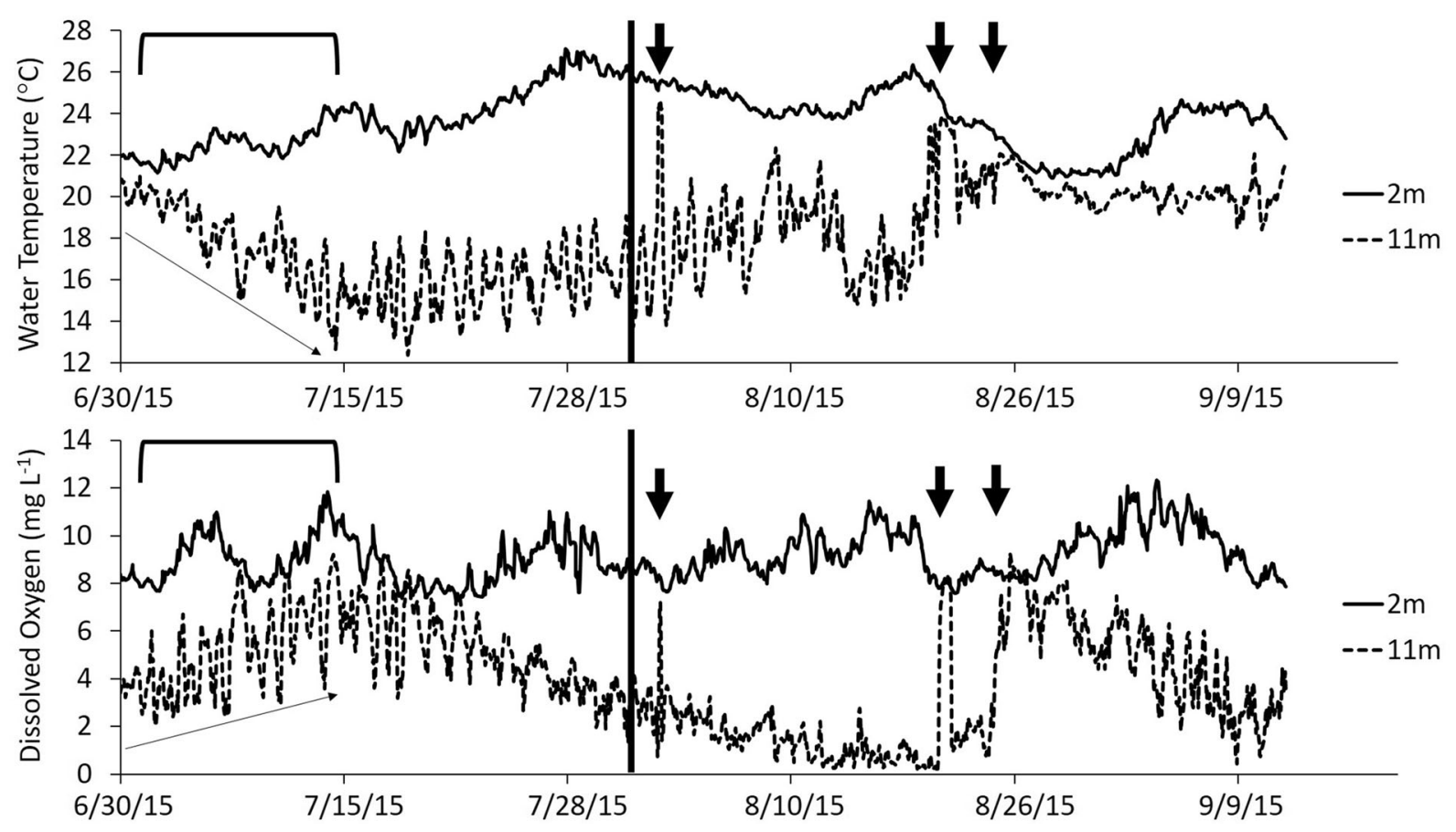

Figure 3. Hourly time-series water temperature $(\mathbf{A})$ and dissolved oxygen $(\mathbf{B})$ data from the Muskegon Lake Observatory buoy, for approximately one month before and during the August wind events (marked by downward pointing arrows). The vertical thick bar divides these two time periods. Diagonal arrows in early July define the decreasing water temperature and increased dissolved oxygen associated with an intrusion of Lake Michigan water into the bottom of Muskegon Lake.

Table 2. Characteristics of Three Major Wind Events that Occurred During August 2015

\begin{tabular}{llll}
\hline Date & Duration $(\mathrm{h})$ & Average wind speed $\left(\mathrm{m} \mathrm{s}^{-1}\right)$ & Mixing depth $(\mathrm{m})$ \\
\hline $8 / 2 / 2015$ & 13 & 11.1 & 11 \\
$8 / 20 / 2015$ & 40 & 10.6 & 11 \\
$8 / 23-24 / 2015$ & 34 & 9.9 & 11
\end{tabular}

Event duration is defined by the first and last measured wind speeds of over $7.7 \mathrm{~m} \mathrm{~s}^{-1}$ (15 knots), which lead to significant mixing of the water column. Average wind speed is the average of wind speeds recorded during the event. Mixing depth is the depth that apparent mixing occurs according to the Muskegon Lake Observatory buoy.

South $\left(p=2.53 \times 10^{-8}, r^{2}=0.70, \quad F_{1,26}=61.58\right.$ $(\mathrm{SRP})=-0.088 \pm 0.011(\mathrm{DO})-1.32)$, with higher concentrations of SRP occurring at lower concentrations of DO. Linear equations here and throughout the methods section are presented with rate \pm standard error.

Measurable amounts of TP were always present in the surface and bottom waters. Surface concentrations of TP stayed the same or slightly increased from spring until fall (Supplemental Figure 2B). Surface and bottom concentrations were similar in the spring and fall, but bottom TP ranged higher in the summer during hypoxia as the SRP component of TP increases. TP also was more stable during hypoxia at the deeper locations, whereas East and Buoy had to rebuild TP concentrations from background levels as a result of the August mixing events.

The regression tree for $\mathrm{TP}$ acted in a similar manner to the SRP tree, but with a few differences. The first bifurcation also happened at $\mathrm{DO}=3.0$ $\mathrm{mg} \mathrm{L}^{-1}$ DO, with an average TP concentration of $0.0481 \mathrm{mg} \mathrm{L}^{-1}$ occurring at less than $3.0 \mathrm{mg} \mathrm{L}^{-1}$ DO while an average TP concentration of $0.0240 \mathrm{mg} \mathrm{L}^{-1}$ occurs above (Figure $4 \mathrm{C}$ ). The tree further divides the low DO group at $1.5 \mathrm{mg} \mathrm{L}^{-1}$ DO, and again the group below $1.5 \mathrm{mg} \mathrm{L}^{-1}$ DO had $1.3 \times$ higher TP concentrations. The group above $3.0 \mathrm{mg} \mathrm{L}^{-1} \mathrm{DO}$ is bifurcated at $\mathrm{DO}=6.8 \mathrm{mg} \mathrm{L}^{-1}$, with the low DO side having 1.65 higher average TP concentrations. There were no substantial site 
A

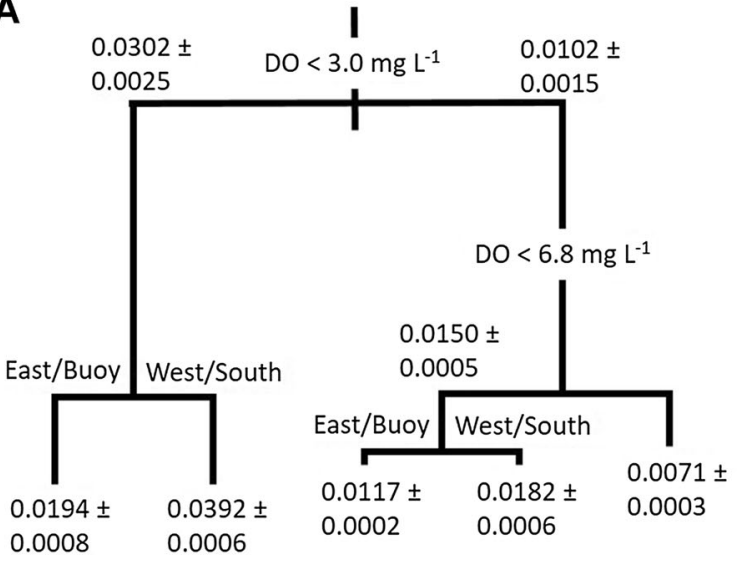

C

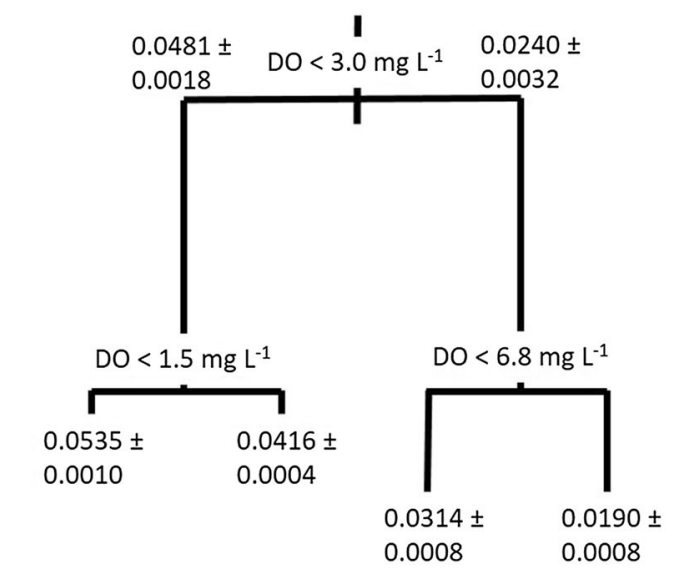

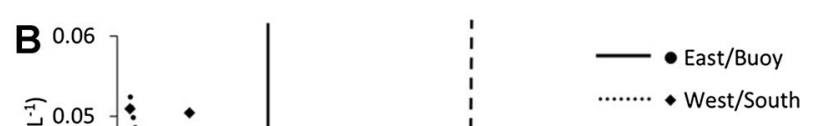
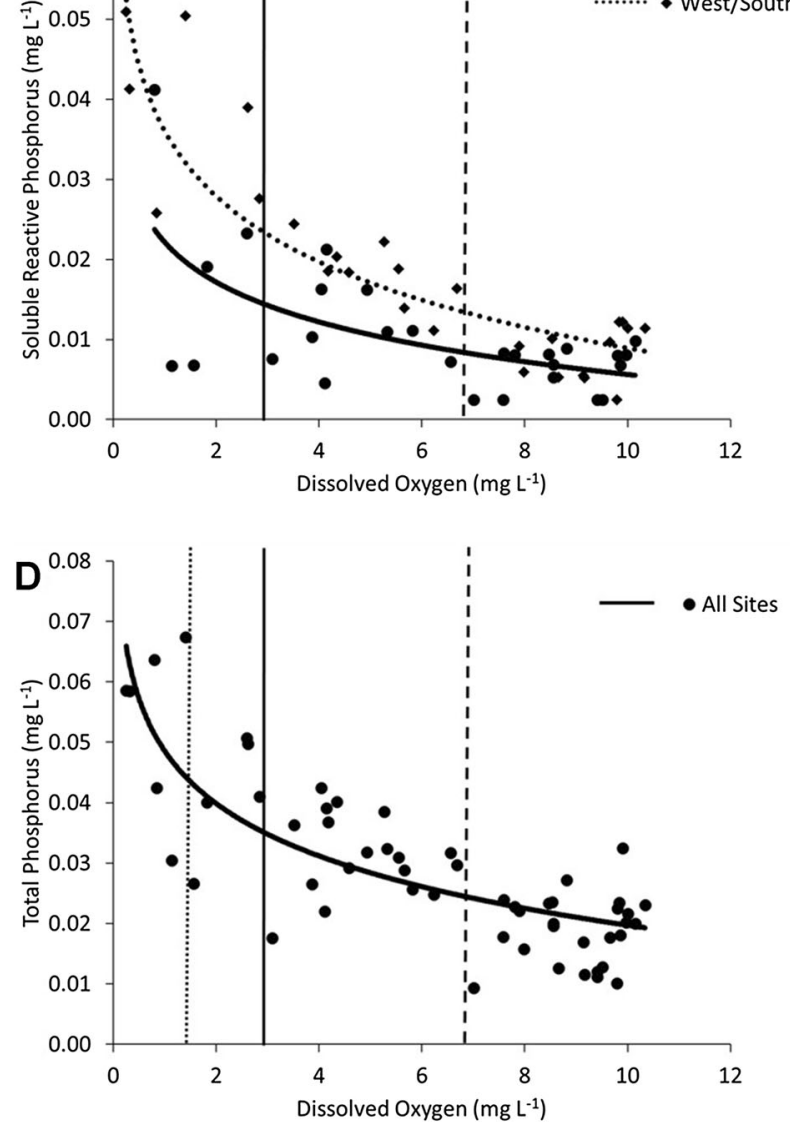

Figure 4. A CART analysis for soluble reactive phosphorus (SRP). Numbers at corners and end of lines represent concentrations $\mathrm{mg} \mathrm{L}^{-1} \pm$ variance. When a division occurs at DO, less than that DO goes left and more than goes right. When division occurs at site location, similar groups of sites are labeled at corners, B graph of SRP versus DO. Curved lines represent the log regression for East/Buoy (solid) and West/South (dotted). Vertical lines are for the tree divisions at $3.0 \mathrm{mg} \mathrm{L}^{-1}$ (solid) and $6.8 \mathrm{mg} \mathrm{L}^{-1}$ (dashed) DO, C CART analysis for total phosphorus (TP). Follows same interpretation as A, D graph of TP versus DO. Solid curved line represents the log regression for all sites combined. Vertical lines represent the tree divisions at $1.5 \mathrm{mg} \mathrm{L}^{-1}$ (dotted), $3.0 \mathrm{mg} \mathrm{L}^{-1}$ (solid), and $6.8 \mathrm{mg} \mathrm{L}^{-1}$ (dashed) DO.

differences, so all four sites were grouped together. Like SRP, a graph of TP concentration versus DO revealed a log relationship (Figure 4D). The linear regression of log-transformed TP data versus DO yielded a significant relationship $\left(p=1.79 \times 10^{-11}\right.$, $r^{2}=0.57, \quad F_{1,54}=71.6 \quad(\mathrm{TP})=-0.049 \pm 0.006$ (DO) - 1.28), which also showed increasing TP concentrations with decreasing DO.

$\mathrm{NH}_{3}$ had the least obvious patterns of the four nutrients measured. For the most part, $\mathrm{NH}_{3}$ concentrations varied greatly week to week (Supplemental Figure 2C). There was no obvious difference between surface and bottom concentrations in relation to hypoxia.
The tree for $\mathrm{NH}_{3}$ divided first at site (Figure 5A). The East site had higher average $\mathrm{NH}_{3}$ concentrations of $0.0395 \mathrm{mg} \mathrm{L}^{-1}$, than did the Buoy, West, and South sites of $0.0290 \mathrm{mg} \mathrm{L}^{-1}$. Within the East site, $1.8 \mathrm{x}$ higher concentrations were measured when DO was less than $5.9 \mathrm{mg} \mathrm{L}^{-1}$. Within the other three sites, $\mathrm{NH}_{3}$ concentrations were actually $1.7 \times$ higher when the DO was greater than $5.6 \mathrm{mg} \mathrm{L}^{-1}$. $\mathrm{NH}_{3}$ versus $\mathrm{DO}$ at the East site showed a linear relationship $\left(p=6.04 \times 10^{-5}\right.$, $r^{2}=0.78, \quad F_{1,11}=39.38 \quad(\mathrm{SRP})=-0.0063 \pm 0.0010$ $(\mathrm{DO})+0.084)$ when one extreme outlier was removed, which indicated higher $\mathrm{NH}_{3}$ concentrations at lower DO (Figure 5B). The other three sites 
together did not show any significant relationship to DO.

Surface and bottom concentrations of TKN changed differently through the season. TKN concentrations at the surface increased from spring to the middle of the summer and then fell at a similar rate into the fall (Supplemental Figure 2D). TKN was similar at surface and bottom in the spring and fall. Bottom TKN decreased from later spring to late summer and then increased into the fall.

The tree for TKN divided first at site, similar to $\mathrm{NH}_{3}$ (Figure 5C). It first grouped East/Buoy and West/South, with East/Buoy having slightly higher concentrations of TKN $\left(0.4681 \mathrm{mg} \mathrm{L}^{-1}\right)$ than West/ South $\left(0.4020 \mathrm{mg} \mathrm{L}^{-1}\right)$. Within East/Buoy, TKN was $1.3 \mathrm{x}$ higher at DO less than $8.7 \mathrm{mg} \mathrm{L}^{-1}$. West/
South had $1.35 \mathrm{x}$ higher concentrations at DO greater than $3.8 \mathrm{mg} \mathrm{L}^{-1}$. Neither East/Buoy nor West/South showed a clear relationship between TKN and DO (Figure 5D).

\section{Bacterial Abundance}

BA at the surface and bottom was similar in the spring and fall, but spring abundances were higher than in the fall (Supplemental Figure 3). During the summer, the surface BA was typically higher in the surface waters compared to the bottom. Bottom BA revealed a similarity between the East and Buoy sites and the West and South sites, with those two groups responding differently to changing conditions and seasons.
A

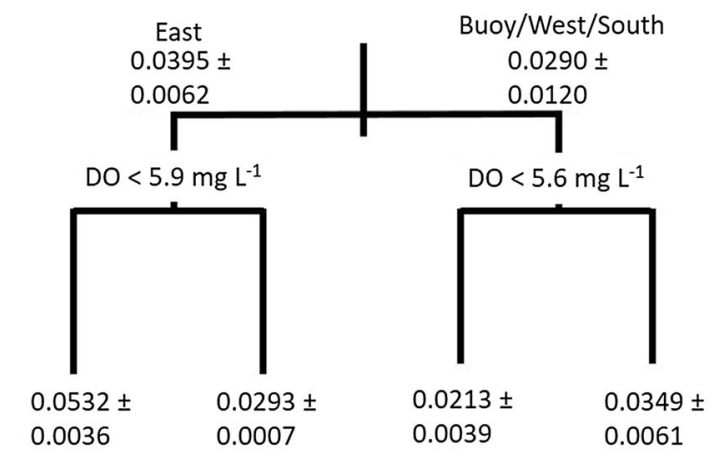

C

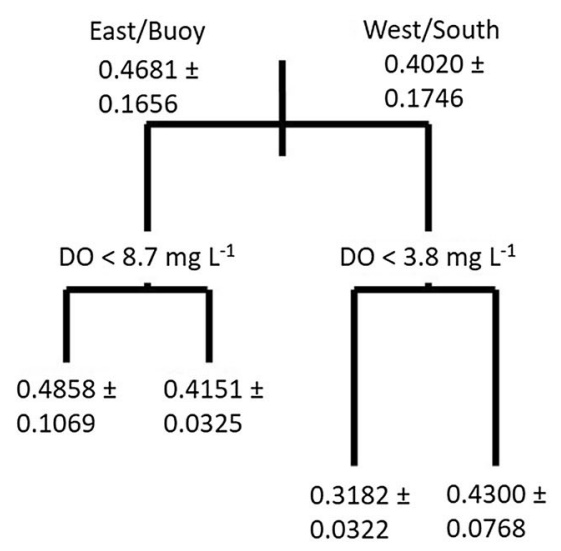

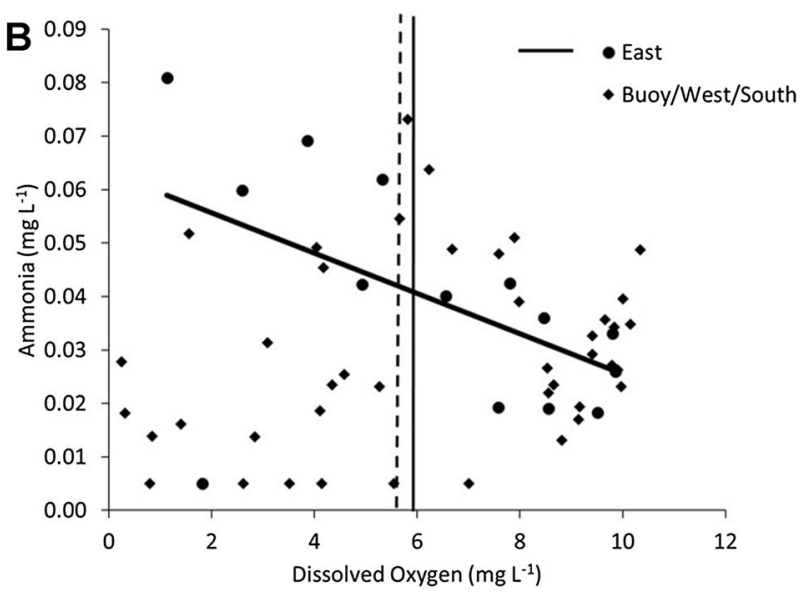

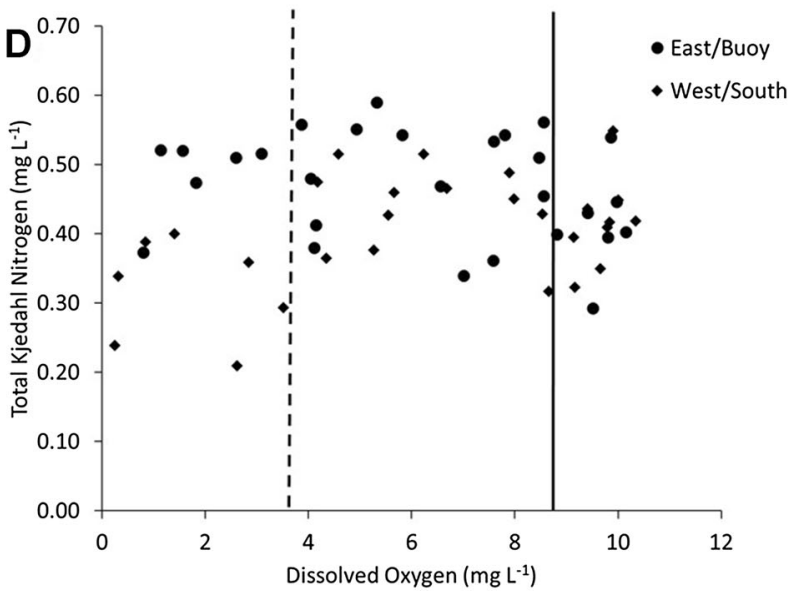

Figure 5. A CART analysis for ammonia $\left(\mathrm{NH}_{3}\right)$. Numbers at corners and end of lines represent concentrations mg $\mathrm{L}^{-1} \pm$ variance. When a division occurs at DO, less than that DO goes left and more than goes right. When division occurs at site location, similar groups of sites are labeled at corners, B graph of $\mathrm{NH}_{3}$ versus DO. Solid diagonal line represents the linear regression for East (solid). Vertical lines are for the tree divisions at $5.9 \mathrm{mg} \mathrm{L}^{-1}$ (solid) and $5.6 \mathrm{mg} \mathrm{L}^{-1}$ (dashed) DO. C CART analysis for total Kjeldahl nitrogen (TKN). Follows same interpretation as A, D graph of TKN versus DO. Vertical lines represent the tree divisions at $8.7 \mathrm{mg} \mathrm{L}^{-1}$ (solid) and $3.8 \mathrm{mg} \mathrm{L}^{-1}$ (dashed) DO. 
The abundance of bacteria changed with respect to DO (Figure 6A). The tree first divided BA at $\mathrm{DO}=9.8 \mathrm{mg} \mathrm{L}^{-1}$, showing decreased abundance (336,800 cells $\left.\mathrm{mL}^{-1}\right)$ above $9.8 \mathrm{mg} \mathrm{L}^{-1}$ DO compared to 611,100 cells $\mathrm{mL}^{-1}$ below. Below $9.8 \mathrm{mg} \mathrm{L}^{-1} \mathrm{DO}, \mathrm{BA}$ was divided at $2.2 \mathrm{mg} \mathrm{L}^{-1} \mathrm{DO}$, as above this concentration BA was $1.3 \mathrm{x}$ higher. Within the 2.2-9.8 $\mathrm{mg} \mathrm{L}^{-1}$ DO range, East had a $1.3 \times$ higher average BA than did the Buoy, West, and South groups. Despite these patterns, no linear or log relationships with respect to DO were evident (Figure 6B).

\section{Chlorophyll a and Phycocyanin}

Three separate strong wind events occurred on $8 / 2$, $8 / 20$, and $8 / 23-24$, which homogenized the water column at the buoy location to the bottommost sensors. The event on 8/23-24 led to a late summer turnover event, whereby the entire lake was mixed down to 10-11 meters. The lake-wide average of phycocyanin concentrations $(3579 \pm 491$ cells $\left.\mathrm{mL}^{-1}\right)$ in the three samples $(6 / 30,7 / 15,7 / 28)$ before $8 / 2$ were significantly lower $(W=0$, $P<0.001)$ than phycocyanin concentrations (11232 \pm 760 cells $\mathrm{mL}^{-1}$ ) afterward (8/10, 8/26, 9/ 9; Table 3, Figure 7). Although there was a slight increase, chlorophyll a concentrations were not significantly different before $\left(6.7 \pm 0.3 \mu \mathrm{g} \mathrm{L}{ }^{-1}\right)$ or after $\left(7.8 \pm 0.5 \mu \mathrm{g} \mathrm{L}^{-1}\right) 8 / 2$. Water temperatures also were also not significantly different prior to $\left(23.8 \pm 0.5^{\circ} \mathrm{C}\right)$ or following $\left(22.8 \pm 0.4^{\circ} \mathrm{C}\right)$ the $8 / 2$ event (Table 3, Figure 7).

\section{Fish}

The catch of benthic fishes in the vicinity of the MLO in Muskegon Lake changed drastically as seasonal hypoxia developed within the lake's hypolimnion. Total catch over the 11 sampling dates yielded 201 fish comprised of 11 different species. The overall most abundant fish species in the catch were yellow perch (Perca flavescens), spottail shiner (Notropis hudsonius), white perch (Morone americana), and walleye (Sander vitreus) (Table 4). During peak DO on November 4, 2015, 67 fish comprised of nine species were caught. This represented the highest abundance and number of species of all sampling trips. During the lowest period of DO, no fish were caught. This represented the lowest abundance and number of species of all sampling trips. Catch during hypoxia was almost entirely composed of yellow perch, with only three other species (white perch, walleye, and alewife) captured in low abundances under the same conditions. Fish total length also changed with decreasing DO (Figure 8). Maximum fish lengths tended to decrease as hypoxia formed. In contrast, minimum fish size changed very little over the course of the season.

All regressions yielded significant relationships with DO. Benthic fish abundance near the MLO increased as DO increased $\left(p<0.001, R^{2}=0.74\right.$, $F_{1,9}=26.06, \quad$ abundance $=0.603 \pm 0.118 \quad(\mathrm{DO})$ +0.776 ; Figure 6). Number of species increased as DO increased $\left(p<0.001, R^{2}=0.81, F_{1,9}=38.16\right.$, number of species $=0.257 \pm 0.042(\mathrm{DO})+0.455$;
A

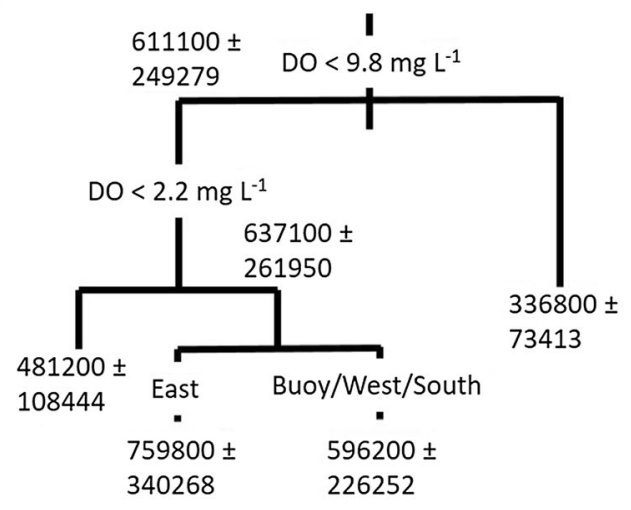

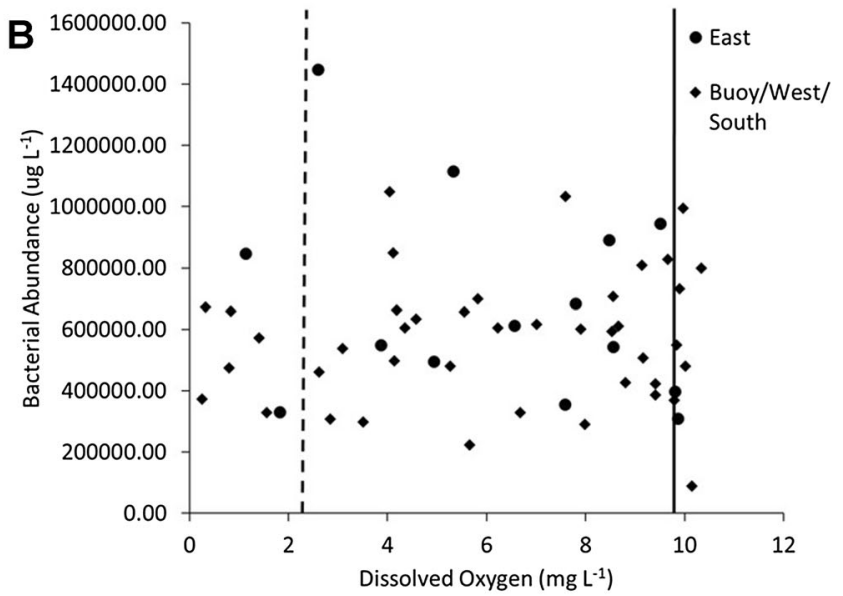

Figure 6. A CART analysis for bacterial abundance (BA). Numbers at corners and end of lines represent concentrations cells $\mathrm{mL}^{-1} \pm 1$ standard deviation. When a division occurs at DO, less than that DO goes left and more than goes right. When division occurs at site location, similar groups of sites are labeled on lines, B graph of BA versus DO. Vertical lines are for the tree divisions at $9.8 \mathrm{mg} \mathrm{L}^{-1}$ (solid) and $2.2 \mathrm{mg} \mathrm{L}^{-1}$ (dashed) DO. 
Table 3. Water Temperature, Chlorophyll $a$, and Phycocyanin Averages from 1 to $2 \mathrm{~m}$ Depth During Summer 2015 in Muskegon Lake, Michigan

\begin{tabular}{llll}
\hline Date & Water Temperature $\left({ }^{\circ} \mathrm{C}\right)$ & Chlorophyll $\left(\mu \mathrm{g} \mathrm{L}^{-1}\right)$ & ${\text { Phycocyanin }\left(\mathrm{cells} \mathrm{mL}^{-1}\right)}^{2}$ \\
\hline $6 / 30 / 2015$ & 21.7 & 6.0 & 1952 \\
$7 / 15 / 2015$ & 23.3 & 7.4 & 3983 \\
$7 / 28 / 2015$ & 26.1 & 6.9 & 4801 \\
$8 / 10 / 2015$ & 23.9 & 9.7 & 12369 \\
$8 / 26 / 2015$ & 21.1 & 7.4 & 10749 \\
$9 / 9 / 2015$ & 23.3 & 6.4 & 10578
\end{tabular}

Roman dates are prior to a series of major wind events during August, whereas italicized dates are during and after the wind events.
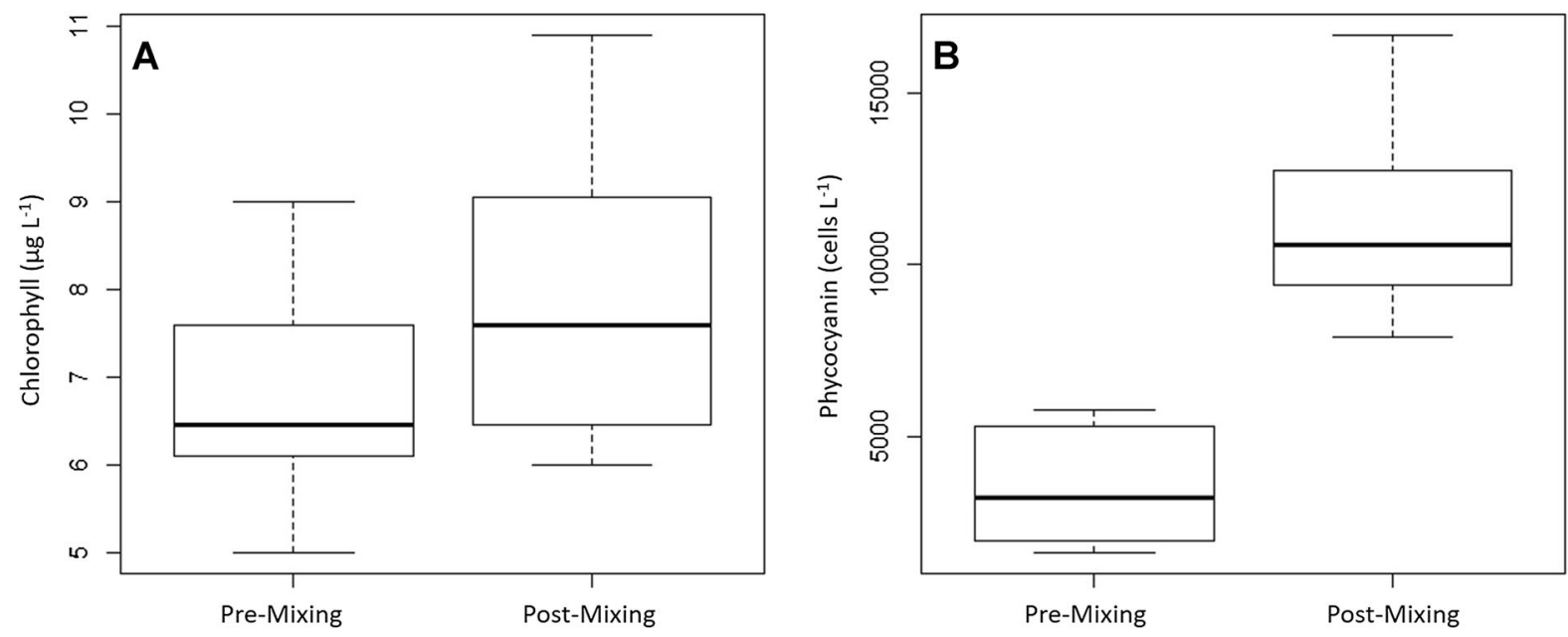

Figure 7. 1-2 m average A chlorophyll and $\mathbf{B}$ phycocyanin concentrations from three sample dates before and after the initial 8/2/2015 mixing event. Thick central line represents the median, the box represents the second and third quartiles, and the dashed lines represent the outer first and fourth quartiles.

Table 4. Dissolved Oxygen Concentration and Fish Caught in Experimental Gill Nets on Different Sampling Dates During 2015 in Muskegon Lake, Michigan, at Approximately $12 \mathrm{~m}$ Depth

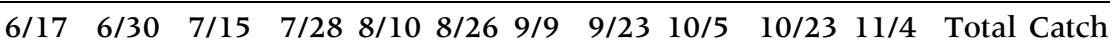
Per Species

Dissolved oxygen $\left(\mathrm{mg} \mathrm{L}^{-1}\right)$

Yellow perch (Perca flavescens)

Spottail shiner (Notropis hudsonius)

White perch (Morone americana)

Walleye (Sander vitreus)

Alewife (Alosa pseudoharengus)

Channel catfish (Ictalurus punctatus)

Freshwater drum (Aplodinotus grunniens)

Northern pike (Esox lucius)

White sucker (Catostomus commersonii)

Longnose gar (Lepiosteus osseus)

Smallmouth bass (Micropterus dolomieu)

Total catch per date

$\begin{array}{rrrrlllllllrrr}5.65 & 2.65 & 4.26 & 3.13 & 1.43 & 2.58 & 0.65 & 2.60 & 8.78 & 9.93 & 10.09 & \\ 28 & 14 & 10 & 5 & 1 & 4 & & 6 & 1 & 4 & 16 & 89 \\ 3 & & & & & & & & 2 & 9 & 19 & 33 \\ 1 & & & & & 2 & & 1 & 4 & 12 & 8 & 28 \\ & & & & & & & 1 & 1 & 1 & 15 & 18 \\ & & & & & & & 1 & 1 & & 6 & 8 \\ & & & & & & & & 2 & 5 & 1 & 8 \\ & & & & & & & & 2 & 4 & 2 & 8 \\ 2 & & & & & & & & 2 & 1 & 1 & 6 \\ 1 & & & & & & & & & & & 1 \\ & & & & & & & & & 1 & & 1 \\ & & & & & & & & & & 1 & 1 \\ 35 & 14 & 10 & 5 & 1 & 6 & 0 & 9 & 15 & 37 & 69 & 201\end{array}$


Figure 8). Minimum fish length was fairly consistent across DO concentrations, ranging between 9 and $11 \mathrm{~cm}$. Maximum $\left(p<0.00001, R^{2}=\right.$ $0.91, F_{1,9}=91.06$, maximum length $=6.81 \pm 0.71$ (DO) - 2.66; Figure 8) fish lengths increased as DO increased.

\section{Discussion}

\section{Internal Loading of Phosphorus}

SRP and TP were both significantly higher in the bottom waters during summer hypoxia compared to periods when regular reoxygenation of bottom waters occurred. Concentrations of these nutrients were most elevated at DO below $3.0 \mathrm{mg} \mathrm{L}^{-1}$ and still elevated below $6.8 \mathrm{mg} \mathrm{L}^{-1}$ relative to higher oxygenated conditions. The patterns seen in SRP and TP with respect to DO agree with what other studies have shown before (Testa and Kemp 2012). Steinman and others (2008) also indicated high bottom-water SRP concentrations Muskegon Lake from 2003 to 2005, and Salk and others 2016 did so as well in 2012-2013. The same pattern is observed in 2015, although bottom SRP concentrations ranged much higher in the current study than either of the two previous studies. Interestingly, the West and Deep sites showed higher concentrations of SRP during hypoxia compared to the East and Buoy sites. This may be due to depth differences among the sub-basins, as the West and especially the South site are deeper than the other two sites and occur on the same side of the lake. The depth aids in stabilization of the hypolimnion, which would allow for greater time for hypoxia to develop and SRP to build up between mixing events. During 2003 and 2004, deep sites in similar locations to South and West showed higher concentrations of $\mathrm{TP}$ in the bottom waters during the summer (Steinman and others 2008).

The high SRP concentrations of bottom waters during hypoxia, and even elevated SRP below $6.8 \mathrm{mg} \mathrm{L}^{-1}$ DO suggest that even mild hypoxia is causing internal loading from the sediments. Rates of release of inorganic phosphorus from sediments are known to increase under low-oxygen conditions, so the high SRP in hypoxic waters of Muskegon Lake come as no surprise (Zhang and others 2010; Smith and others 2011; Nürnberg and others 2013). Typically, higher SRP release rates from sediments occur when the DO concentration in the overlying water is less than $2 \mathrm{mg} \mathrm{L}^{-1}$ (Testa and Kemp 2012). However, other studies have noted increased SRP concentrations in hypolimnetic water even when DO concentration $1 \mathrm{~m}$
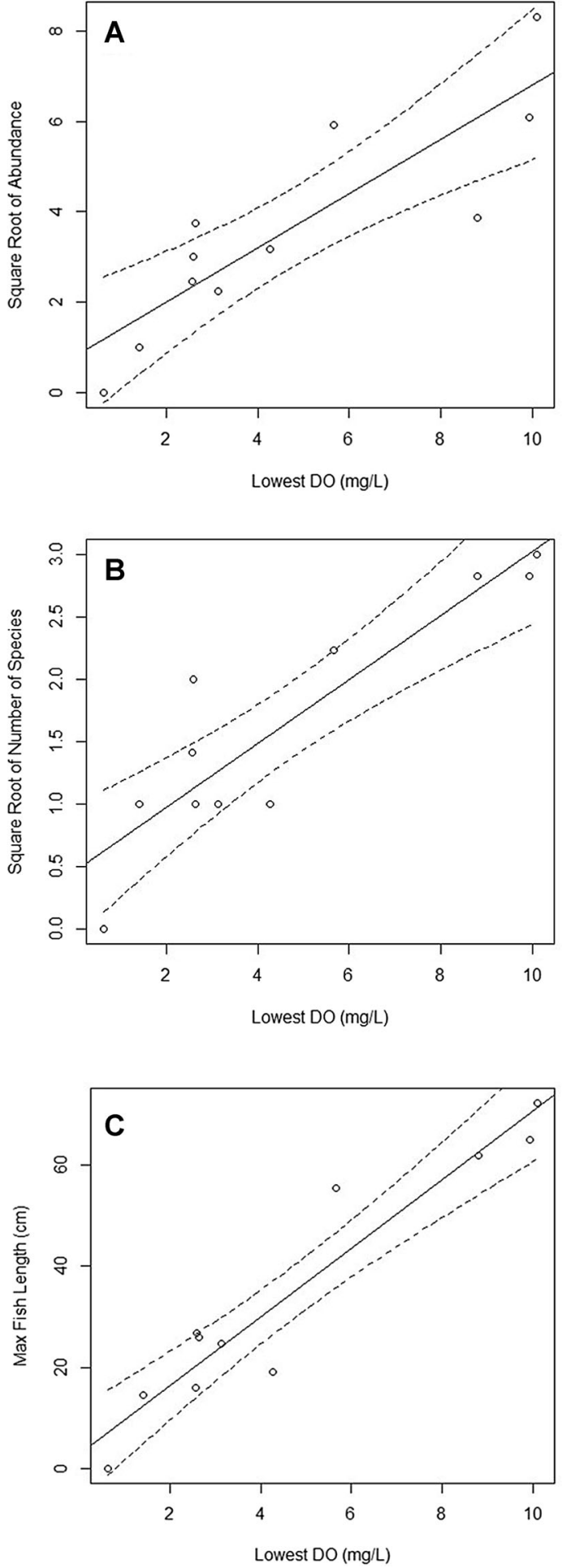

Figure 8. Linear regressions of $\mathbf{A}$ fish abundance (total catch), B number of species, and $\mathbf{C}$ maximum length, against dissolved oxygen concentration in the hypolimnion of Muskegon Lake, Michigan. Solid line represents the linear regression, and the dashed line represents the $95 \%$ confidence interval. 
above the sediment is $3-4 \mathrm{mg} \mathrm{L}^{-1}$, which is a common occurrence during the summer in Muskegon Lake. The sediments of Muskegon Lake are organically rich due to high productivity within the lake and supply from the Muskegon River, which means that there is a lot of carbon to be respired, drawing down DO concentrations quickly (Marko and others 2013; Dila and Biddanda 2015). Under these hypoxic conditions, SRP would be reduced and released from the sediments. Respiration and nutrient mineralization in the water column, specifically the hypolimnion, may also be a source of SRP, as water column respiration has been shown to be the main source of hypoxia generation in Lake Erie and The Gulf of Mexico (Conroy and others 2011; McCarthy and others 2013). Although several studies have indicated that summer is a period of high internal phosphorus loading in two nearby drowned river-mouth lakes (Steinman and others 2004, 2009), another indicates that there is relatively little internal load compared to external load in a different nearby lake (Steinman and Ogdahl 2006). More experiments using hypolimnetic water and sediment core incubations would be needed to further determine what the exact internal source of the SRP is in Muskegon Lake.

The patterns with the nitrogen species of $\mathrm{NH}_{3}$ and TKN were less clear and seemed not to be related to hypoxia formation. We would expect $\mathrm{NH}_{3}$ to increase similarly to SRP with hypoxia formation (Zhang and others 2010; Testa and Kemp 2012). Unlike SRP and TP, $\mathrm{NH}_{3}$ and TKN did not increase in concentration in the hypoxic period at most sites. The East site was the only one that showed a consistent relationship of decreasing DO and increasing $\mathrm{NH}_{3}$. Although not all studies agree on the exact DO concentration at which $\mathrm{P}$ and $\mathrm{N}$ release from sediments, the suggested range goes from below $2 \mathrm{mg} \mathrm{L}^{-1}$ to below $0.5 \mathrm{mg} \mathrm{L}^{-1}$ (Mortimer 1941; Schön and others 1993; Testa and Kemp 2012). All sites reached DO concentrations at some point where $\mathrm{N}$ should have been released as well as $\mathrm{P}$, although South was the only site consistently below $2 \mathrm{mg} \mathrm{L}^{-1}$. A recent study on Muskegon Lake found that its hypoxic waters are a strong source of $\mathrm{N}_{2} \mathrm{O}$, with high amount released during mixing events (Salk and others 2016). Thus, it is possible that nitrogen generated under hypoxic conditions is being transformed to $\mathrm{N}_{2} \mathrm{O}$ rather than the expected ammonia in Muskegon Lake. This pathway may be favored as opposed to reduction to ammonium, which only occurs at very low DO concentrations, whereas $\mathrm{N}_{2} \mathrm{O}$ production consistently increases as oxygen decreases (Goreau and others 1980).

\section{Bacteria}

BA responded negatively to DO concentrations below $2.2 \mathrm{mg} \mathrm{L}^{-1}$ as well as above $9.8 \mathrm{mg} \mathrm{L}^{-1}$. The decreased abundance at high DO may be related to the fact that high DO concentrations occur during the spring and fall when water temperatures are colder compared to the summer, reducing bacterial activity (Shiah and Ducklow 1994). The negative response of bacteria to very low DO agrees with previous studies. In the hypoxic hypolimnion of Lake Erie, bactivory is increased, and a similar phenomenon may be outpacing bacterial production in Muskegon Lake leading to lower abundances (Gobler and others 2008). Increased viral lysis under hypoxic conditions may be an additional source of phosphorus in the bottom waters (Gobler and others 2008). And in Chesapeake Bay, some bacteria may be inhibited by low-oxygen conditions (Shiah and Ducklow 1994).

Though there was great variation in abundances in the present study, the abundances are similar to what has been seen in other freshwater lakes. We saw BA range from 90 thousand to 1.45 million. Other studies have seen ranges within the bottom of Lake Erie to be from 290 to 750 thousand (Gobler and others 2008), and a synthesis study saw between 500 thousand to 4.1 million in a variety of freshwater lakes (Bird and Kalff 1984). In Muskegon Lake surface water from 2003 to 2005, BA ranged from less than 100 thousand to over 1.6 million $\mathrm{mL}^{-1}$ (Steinman and others 2008). This study's abundances fall on the lower end of that seen in other studies, which is expected as bottomwater BA is typically lower than that of surface waters.

The similarity in BA before and during mild hypoxia periods suggests that the bacterial community in the spring already has the potential to decrease bottom waters to hypoxic levels; however, spring mixing and lack of stratification continually supply the bottom with DO. This may explain why DO in the hypolimnion immediately starts to decrease following even weak thermal stratification. The BA similarity is also puzzling considering the high productivity in the surface waters during the summer (Weinke and others 2014; Dila and Biddanda 2015). However, it is possible that there is enough excess algal production in the surface waters that sinks to the bottom to be decomposed. The BA during summer at the surface is roughly $36 \%$ higher than at the bottom, which suggests perhaps much of the bacterial processing of algal production occurs in the surface waters. In the Black Sea, about $60 \%$ of surface algal production was esti- 
mated to have been broken down by bacteria (Morgan and others 2006). Thus, the high BA in the surface waters during the summer is logical, as many other systems have noted higher abundance in the oxic surface waters (Morgan and others 2006; Zaikova and others 2010). Perhaps enough surface production is sinking down to fuel the hypolimnetic bacterial community since chl $a$ has been shown to be a predictor of the BOD that depletes DO to hypoxic levels (Mallin and others 2006).

Although the current study did not attempt to evaluate whether there was a change in the bacterial community composition as a response to hypoxia, other studies have shown that the hypolimnetic bacterial community does transition to more hypoxia- and anoxia-tolerant species (Crump and others 2007; Zaikova and others 2010). In Lake Taihu, China, the bacterial community composition changed along with DO and was dominated during hypoxic times by different species than during pre- or post-hypoxic times ( $\mathrm{Li}$ and others 2012). These species are suspected to be related to decomposition of Microcystis, which is abundant in Muskegon Lake (Steinman and others 2008).

\section{Cyanobacterial Blooms During and Following Major Mixing Events}

Despite the slight increases in phycocyanin through July before the August mixing events, there were significant differences between the phycocyanin concentrations of the three sampling periods before the $8 / 2 / 15$ event and the three sampling periods following. Surface scums of Microcystis were not visible on Muskegon Lake until the late August and early September sampling trips.

We investigated several possible causes for the cyanobacterial blooms to form, such as temperature, runoff of nutrients from the river, and entrainment of hypolimnetic nutrients due to mixing events (Paerl and Huisman 2008; Nürnberg and others 2013). Cyanobacteria often bloom under warm water conditions that prevail in the late summer (Paerl and Huisman 2008); however, a comparison of the air temperatures measured by the MLO from before and after the 8/2/15 wind event shows no significant change in air temperature. In fact, several of the wind events that occurred in August were accompanied by approximately $10^{\circ} \mathrm{C}$ drops in air temperature.

To evaluate the influence of nutrients delivered by the river, we looked at the surface nutrient concentrations. We specifically looked for an in- creased nutrient concentration in the surface of the East site in the most recent samples following precipitation events, which is the closest site to where the Muskegon River flows into Muskegon Lake. The river temperature more closely matches that of the surface waters than the bottom waters during the summer, so river water containing increased nutrient concentrations would be seen in the surface of the East site compared to the bottom. However, there were no obvious trends of increasing surface nutrients that were worth investigating for the four nutrient species measured that would help fuel a cyanobacterial bloom.

The last and most plausible cause of the cyanobacterial bloom was wind-induced mixing events. It is important to note that wind mixing has often been cited as the "algal equalizer," because the buoyancy control by some cyanobacteria cannot overpower wind mixing (Huisman and others 2004). During periods of high wind, cyanobacteria are circulated and mixed throughout the water column. However, this is only effective if the mixing is continuous. Periodic mixing of the water column can be ineffective at mitigating cyanobacterial blooms (Jöhnk and others 2008). Nutrients, specifically phosphorus in freshwater systems, are regenerated in bottom waters during hypoxia through decomposition/mineralization and anoxic sediment release (Paerl and others 2011; Nürnberg and others 2013). These nutrients that are normally isolated in these bottom waters due to stratification can then be mixed into the surface waters during strong episodic mixing events-fueling surface blooms (Kamarainen and others 2009; Crockford and others 2014).

Although no obvious trends of decreasing nitrogen species occurred in the bottom waters in the study following the strong mixing events of $\mathrm{Au}$ gust, both SRP and TP show decreases in the bottom waters at the two shallowest sites, East and Buoy, on the eastern side of the lake. MLO water profile data from the Buoy site indicate that the thermocline was significantly deepened by these mixing events, especially the event over the course of $8 / 23$ and $8 / 24$ that kept the thermocline around $10 \mathrm{~m}$ for a few days. Studies of thermal profiles from the East and Buoy locations indicate that through August into early September, the thermocline was 10-11 m deep. Thus, the wind-mixing events caused significant mixing and deepening of the thermocline at the East and Buoy locations, leading to a decrease in bottom SRP and TP. These nutrients were potentially mixed into the surface waters during the wind events, supplying the needed limiting phosphorus for cyanobacteria to 
bloom (Kamarainen and others 2009; Nürnberg and others 2013; Crockford and others 2014). Due to the fact that surface SRP decreases in the summer to undetectable levels, while nitrogen species stay the same or increase, we can hypothesize that the surface algal community is P-limited. This only increases the importance of episodic supplies of phosphorus-rich water to a phosphorus-limited system,

Additionally, there were only a few weaker wind events that occurred between or after the three significant ones noted here. This gave the cyanobacteria calm periods between the wind events, enough time for them to rise back to the surface and continue to bloom. Calm conditions following the wind events are especially important to allow the cyanobacteria to bloom (Paerl and Huisman 2008; Paerl and Otten 2008), which further strengthens the notion that while mixing events do spread cyanobacteria throughout the water column and bring some DO to the hypoxic waters, temporary mixing may be ineffective at mitigating HAB's and hypoxia (Jöhnk and others 2008).

\section{Disappearance of Fish from the Hypolimnion}

Overall, there was a dramatic difference in the abundance, number of species, and size of benthic fish that were caught in the hypolimnion near the MLO during hypoxia compared to before or after hypoxia. Although we only caught fish at one relatively deep location in Muskegon Lake, there was a strong correlation between DO and benthic fish presence in the hypolimnion. DO profiles at the other three locations in the lake show similar hypoxic conditions throughout the summer. Given these observations, we expect a similar pattern of lake-wide summer migration of benthic fish out of the hypoxic hypolimnion, which is similar to what was reported for juvenile lake sturgeon (Acipenser fulvescens) in Muskegon Lake (Altenritter and others 2013).

Many other studies have examined fish behavior, mostly those of economic importance, to hypoxia and found similar results. In a laboratory experiment using chambers and gradients of DO saturation, largemouth bass (Micropterus salmoides) actively avoided low saturations of DO (Burleson and others 2001), which is comparable to the species seen in Muskegon Lake. The study also showed that smaller fish stayed in lower DO than larger fish that stayed in higher DO water (Burleson and others 2001). Our results also indicate that smaller fish inhabit lower DO water and that larger fish prefer high DO. Although numerous laboratory experiments have shown that fish avoid hypoxic water (Burleson and others 2001), there are also in situ observations that corroborate these results. Tagged largemouth bass in tributaries of the Chowan River on the US east coast were shown to avoid water less than $1.8 \mathrm{mg} \mathrm{L}^{-1}$ (Brown and others 2015). In the Neuse River Estuary in North Carolina, Atlantic Croaker Micropogonias undulatus were found to avoid hypoxic waters that compressed their habitat to shallow, warm, oxygenated waters (Eby and others 2005). This compression can be vertical as well as horizontal, as trawls in Lake Erie indicate that fishing along the edge of a hypoxic zone results in a higher catch (Kraus and others 2015). The need to actively avoid hypoxia showed that the bay anchovy Anchoa mitchilli occupied shallower waters, which isolated it from its preferred zooplankton prey that could tolerate the hypoxic conditions (Ludsin and others 2009).

The benthic fish in Muskegon Lake could also move upward or horizontally to avoid hypoxia. Sampling fish communities in the mid-water column would provide more information on the potential for benthic fishes to simply move vertically to avoid hypoxia. At the Buoy location, there is a nearby shelf immediately to the West that is only a few meters deep and may provide a refuge via horizontal migration. Lake sturgeon (Acipenser fulvescens) in Muskegon Lake are known to migrate from the deeper portions of the lake to the shallower mouth of the Muskegon River during the summer, so horizontal migration has been seen before in Muskegon Lake (Altenritter and others 2013). With so many options available for hypoxiasensitive fish to go, the change in species and abundances seen at the Buoy possibly reflects a change in fish distribution as opposed to a change in the fish community as a whole.

There have been relatively few studies looking at the response of benthic fish species compositions to hypoxia in freshwater systems or estuaries. A study by Eby and Crowder (2002) showed that all 10 species they looked at avoided DO less than $2 \mathrm{mg} \mathrm{L}^{-1}$ in the Neuse River Estuary. Interestingly, they also found that their avoidance of hypoxia was context dependent, because when hypoxia was spatially expansive fish would go into the hypoxic zone. Similarly, we only captured one species, yellow perch when the DO was less than $2 \mathrm{mg} \mathrm{L}^{-1}$, but these were in extremely low abundances compared to well-oxygenated times. In a study performed in Mercer Bayou, Arkansas, fish species, abundance, and size were all significantly reduced 
at DO concentrations below $0.5 \mathrm{mg} \mathrm{L}^{-1}$ (Killgore and Hoover 2001).

One of the more interesting findings from the fish catches was that yellow perch was the only species found in the hypoxic waters below $2 \mathrm{mg} \mathrm{L}^{-1}$ and was the most abundant species overall. Previous studies have found that in the wild, yellow perch avoid waters below $2 \mathrm{mg} \mathrm{L}^{-1}$, and in the laboratory, consumption of food and overall growth decreases in hypoxic water (Roberts and others $2009,2011)$. In the current study, one yellow perch was caught when the DO was less than $2 \mathrm{mg} \mathrm{L}^{-1}$, whereas 24 were caught when the DO was between 2 and $3 \mathrm{mg} \mathrm{L}^{-1}$. This suggests that indeed $2 \mathrm{mg} \mathrm{L}^{-1}$ is an acceptable definition of hypoxia for yellow perch. As to why a yellow perch was caught in water less than $2 \mathrm{mg} \mathrm{L}^{-1}$, one study in Lake Erie showed that although yellow perch avoid hypoxia, some make frequent dives into hypoxia to feed on benthic macroinvertebrates (Roberts and others 2009). This could also explain why even so many yellow perch were caught in $2-3 \mathrm{mg} \mathrm{L}^{-1}$ water, considering only three other species (3-white perch, 1-walleye, 1-alewife) were captured when DO was that low. Muskegon Lake appears to be an important site for yellow perch, even during times of mild hypoxia (DO $<4 \mathrm{mg} \mathrm{L}^{-1}$ ) when all other fishes avoided this zone at the MLO. Additionally, another study on fish communities in Muskegon Lake also found yellow perch to be the most abundant species in the littoral areas (Bhagat and Ruetz 2011). Their studies also show a significant decrease in littoral yellow perch abundance in the summer, approximately $25 \%$ of the abundance of either spring or fall, as well as in length range (Bhagat and Ruetz 201 1; Janetski and others 2013). Considering yellow perch have been show to migrate either horizontally or vertically to avoid hypoxia in Lake Erie, decreases in yellow perch abundance in both the benthic and littoral areas of Muskegon Lake suggest that they may occupy the limnetic/pelagic areas above the hypoxia in open water (Roberts and others 2009).

\section{ConCLusion}

There are many changes that occurred in the Muskegon Lake ecosystem as a result of the development of summertime hypolimnetic hypoxia. We observed a drastic change in the benthic fish assemblage such as decreases in abundance, number of species, and size that were correlated with low DO concentrations. There appears to be internal loading of phosphorus in bottom waters during hypoxia; however, the same cannot be said for nitrogen. It is also possible that these phosphorusrich bottom waters can be entrained to the surface, during episodic wind-mixing events, which would provide cyanobacteria the fuel to continue the bloom that started during an initial calm, warm period. Although bacterial abundance did not show a pattern with respect to hypoxia, further work should be performed to characterize the bacterial community to identify which, if any, shifts occur in species and abundances of specific species.

A recent report of an overall $2 \%$ decline in DO of the global ocean over the past five decades is cause for concern (Schmidtko and others 2017). Similar changes in the world's freshwater bodies may be not only exacerbating hypoxia, resulting in reduced habitat for fish and invertebrates and altering primary productivity and microbial life, but also increasing the emission of potent greenhouse gasses such as $\mathrm{N}_{2} \mathrm{O}$ from hypoxic zones globally (Salk and others 2016). Although hypoxia may be an entirely natural feature of many freshwater systems, it is becoming increasingly more common and increasing in severity (areal and volumetric) as nutrients accumulate at confluences of watersheds and global warming strengthens thermal stratification. Conditions that promote internal loading of nutrients and global climate change are only continuing to accelerate, making it difficult for Earth's freshwater ecosystems to recover. Despite potential reductions in external loads of nutrients, internal loading and climate change could allow unnatural levels of hypoxia to occur and persist (Allan and others 2012). This could have many consequences for the entire ecosystem from nutrient cycling to primary production, and bacteria to fish.

\section{ACKNOWLEDGEMENTS}

This work was completed as part of AW's Master's thesis project. A US Environmental Protection Agency Great Lakes Restoration Initiative Grant and National Oceanic and Atmospheric Administration University of Michigan-Cooperative Institute for Great Lakes Research grants to BB provided support for the MLO materials and operations. Additional thesis support came from a Grand Valley State University presidential research grant and a Michigan Space Grant Consortium fellowship to AW. Scott Kendall, Tom Holcomb, Steve Long, Leon Gereaux, Michael Snider, Liz Sommers, Adam McMillan, Nick Weber, Morgan Lindback, Saddie Vela, Fallon Januska, Macy Doster, Dirk Koopmans, and Katie Knapp provided the workforce for MLO maintenance and lake-wide profiles. 


\section{OPEN ACCESS}

This article is distributed under the terms of the Creative Commons Attribution 4.0 International License (http://creativecommons.org/licenses/by/ $4.0 /$ ), which permits unrestricted use, distribution, and reproduction in any medium, provided you give appropriate credit to the original author(s) and the source, provide a link to the Creative Commons license, and indicate if changes were made.

\section{REFERENCES}

Allan JD, McIntyre PB, Smith SDP, Halpern BS, Boyer GL, Buchsbaum A, Burton GA Jr, Campbell LM, Chadderton WL, Ciborowski JJH, Doran PJ, Eder T, Infante DM, Johnson LB, Joseph CA, Marino AL, Prusevich A, Read JG, Rose JB, Rutherford ES, Sowa SP, Steinman AD. 2012. Joint analysis of stressors and ecosystem services to enhance restoration effectiveness. Proc Natl Acad Sci U. S. A. 110:372-7.

Altenritter MEL, Wieten AC, Ruetz CRIII, Smith KM. 2013. Seasonal spatial distribution of juvenile Lake Sturgeon in Muskegon Lake, Michigan, USA. Ecol Freshw Fish 22:467-78.

Bhagat Y, Ruetz CRIII. 2011. Temporal and fine-scale spatial variation in fish assemblage in a drowned river mouth system of Lake Michigan. Trans Am Fish Soc 140:1429-40.

Bird DF, Kalff J. 1984. Empirical relationships between bacterial abundance and chlorophyll concentration in fresh and marine waters. Can J Fish Aquat Sci. 41:1015-23.

Brown DT, Aday DD, Rice JA. 2015. Responses of coastal largemouth bass to episodic hypoxia. Trans Am Fish Soc 144:655-66.

Burleson ML, Wilhelm DR, Smatresk NJ. 2001. The influence of fish size on the avoidance of hypoxia and oxygen selection by largemouth bass. J Fish Biol 59:1336-49.

Conroy JD, Boegman L, Zhang H, Edwards WJ, Culver DA. 2011. "Dead Zone" dynamics in Lake Erie: the importance of weather and sampling intensity for calculated hypolimnetic oxygen depletion rates. Aquat Sci 73:289-304.

Crockford L, Jordan P, Melland AR, Taylor D. 2014. Stormtriggered, increased supply of sediment-derived phosphorous to the epilimnion in a small freshwater lake. Inland Waters 5:15-26.

Crump BC, Peranteau C, Beckingham B, Cornwell JC. 2007. Respiratory succession and community succession of bacterioplankton in seasonally anoxic estuarine waters. Appl Environ Microbiol 73:6802-10.

Diaz RJ. 2001. Overview of hypoxia around the world. J Environ Qual 30:275-81.

Diaz RJ, Rosenberg R. 2008. Spreading dead zones and consequences for marine ecosystems. Science 321:926-9.

Dila D, Biddanda BA. 2015. From land to lake: contrasting microbial processes across a Great Lakes gradient of organic carbon and inorganic nutrient inventories. J Great Lakes Res 41:75-85.

Dokulil MT. 2013. Impact of climate warming on European inland waters. Inland Waters 4:27-40.

Eby LA, Crowder LB. 2002. Hypoxia-based habitat compression in the Neuse River Estuary: context-dependent shifts in behavioral avoidance thresholds. Can J Fish Aquat Sci 59:952-65.
Eby LA, Crowder LB, McClellan CM, Peterson CH, Powers MJ. 2005. Habitat degradation from intermittent hypoxia: impacts on demersal fishes. Mar Ecol Prog Ser 291:249-61.

EPA. 1993. Methods for the determination for inorganic substances in environmental samples. USEPA 600/R-93/100.

Freedman P, Canale R, Auer M. 1979. The impact of wastewater diversion spray irrigation on water quality in Muskegon County lakes, Rep. 905/9-79-006-A, U.S. Environmental Protection Agency, Washington, D. C.

Gobler CJ, Davis TW, Deonarine SN, Saxton MA, Lavrentyev PJ, Jochem FJ, Wilhelm SW. 2008. Grazing and virus-induced mortality of microbial populations before and during the onset of annual hypoxia in Lake Erie. Aquat Microb Ecol. 51:11728.

Goreau TJ, Kaplan WA, Wofsy SC, McElroy MB, Valois FW, Watson SW. 1980. Production of $\mathrm{NO}_{2}{ }^{-}$and $\mathrm{N}_{2} \mathrm{O}$ by nitrifying bacteria at reduced concentrations of oxygen. Appl Environ Microb 40:526-32.

Goto D, Lindelof K, Fanslow DL, Ludsin SA, Pothoven SA, Roberts JJ, Vanderploeg HA, Wilson AE, Höök TO. 2012. Indirect consequences of hypolimnetic hypoxia on zooplankton growth in a large eutrophic lake. Aquat Biol 16:217-27.

Hobbie JE, Daley RJ, Jasper S. 1977. Use of nucleopore filters for counting bacteria by epifluorescence microscopy. Appl Environ Microbiol 33:1225-8.

Huisman J, Sharples J, Stroom JM, Visser PM, Kardinaal WEA, Verspagen JMH, Sommeijer B. 2004. Changes in turbulent mixing shift competition for light between phytoplankton species. Ecology 85:2960-70.

Janetski DJ, Ruetz CRIII, Bhagat Y, Clapp DF. 2013. Recruitment dynamics of age- 0 yellow perch in a drowned river mouth lake: assessing synchrony with nearshore Lake Michigan. Trans Am Fish Soc 142:505-14.

Jennings E, Jones S, Arvola L, Staehr PA, Gaiser E, Jones ID, Weathers KC, Weyhenmeyer GA, Chiu C, De Eyto E. 2012. Effects of weather-related episodic events in lakes: an analysis based on high frequency data. Freshw Biol 57:589601.

Jenny JP, Francus P, Normandeau A, LaPointe F, Perga M, Ojala A, Schimmelman A, Zolitschka B. 2016. Global spread of hypoxia in freshwater ecosystems during the last three centuries is caused by rising local human pressure. Global Change Biol 22:1481-9.

Jöhnk KD, Huisman J, Sharples J, Sommeijer B, Visser PM, Strooms JM. 2008. Summer heatwaves promote blooms of harmful cyanobacteria. Global Change Biol 14:495-512.

Kamarainen AM, Penczykowski RM, Van de Bogert MC, Hanson PC, Carpenter SR. 2009. Phosphorous sources and demand during summer in a eutrophic lake. Aquat Sci 71:214-27.

Killgore KJ, Hoover JJ. 2001. Effects of hypoxia on fish assemblages in a vegetated waterbody. J Aquat Plant Manage 39:404.

Kraus RT, Knight CT, Farmer TM, Gorman AM, Collingsworth PD, Warren GJ, Kocovsky PM, Conroy JD. 2015. Dynamic hypoxic zones in Lake Erie compress fish habitat, altering vulnerability to fishing gears. Can J Fish Aquat Sci 72:797806.

Larsson P, Lampert W. 2011. Experimental evidence of a lowoxygen refuge for large zooplankton. Limnol Oceanogr $56: 1682-8$.

Li H, Xing P, Wu QL. 2012. Characterization of the bacterial community composition in a hypoxic zone induced by $\mathrm{Mi}$ - 
crocystis blooms in Lake Taihu, China. FEMS Microbiol Ecol 79:773-84.

Ludsin SA, Zhang X, Brandt SB, Roman MR, Boicourt WC, Mason DM, Costantini M. 2009. Hypoxia-avoidance by planktivorous fish in Chesapeake Bay: implications for food web interactions and fish recruitment. J Exp Mar Biol Ecol 381:5121-31.

Mallin MA, Johnson VL, Ensign SH, MacPherson TA. 2006. Factors contributing to hypoxia in rivers, lakes, and streams. Limnol Oceanogr 51:690-701.

Marko KM, Rutherford ES, Eadie BJ, Johengen TH, Lansing MB. 2013. Delivery of nutrients and seston from the Muskegon River Watershed to near shore Lake Michigan. J Great Lakes Res 39:672-81.

McCarthy MJ, Carini SA, Liu Z, Ostrom NE, Gardner WS. 2013. Oxygen consumption in the water column and sediments of the Gulf of Mexico hypoxic zone. Estuar Coast Shelf Sci 123:46-53.

Morgan J, Quinby H, Ducklow H. 2006. Bacterial abundance and production in the western Black Sea. Deep Sea Res. Limnol Oceanogr 53:1945-60.

Mortimer CH. 1941. The exchange of dissolved substances between mud and water in Lakes. J Ecol 29:280-329.

Nürnberg GK, Molot LA, O'Connor E, Jarjanazi H, Winter J, Young J. 2013. Evidence for internal phosphorous loading, hypoxia and effects on phytoplankton in partially polymictic Lake Simcoe, Ontario. J Great Lakes Res 39:259-70.

Paerl HW, Huisman J. 2008. Blooms like it hot. Science 320:57-8.

Paerl HW, Otten TG. 2008. Blooms bite the hand that feeds them. Science 342:433-4.

Roberts JJ, Höök TO, Ludsin SA, Pothoven SA, Vanderploeg HA, Brandt SB. 2009. Effects of hypolimnetic hypoxia on foraging distributions of Lake Erie yellow perch. J Exp Mar Biol 381:132-42.

Roberts JJ, Brandt SB, Fanslow D, Ludsin SA, Pothoven SA, Scavia D, Höök TO. 2011. Effects of hypoxia on consumption, growth, and RNA:DNA ratios of young- yellow perch. Trans Am Fish Soc 140:1574-86.

Sahoo GB, Schladow SG, Reuter JE, Coats R. 2011. Effects of climate change on thermal properties of lakes and reservoirs, and possible implications. Stoch Environ Res Risk Assess 25:445-56.

Salk KR, Ostrom PH, Biddanda BA, Weinke AD, Kendall ST, Ostrom NE. 2016. Ecosystem metabolism and greenhouse gas production in a mesotrophic northern temperate lake experiencing seasonal hypoxia. Biogeochemistry 131:303-19.

Sanders TG Jr, Biddanda BA, Strickler CA, Nold SC. 2011. Benthic macroinvertebrate and fish communities in Lake Huron are linked to submerged groundwater vents. Aquat Biol 12:1-11.

Scavia D, Allan JD, Arend KK, Bartell S, Beletsky D, Bosch NS, Brandt SB, Briland RD, Daloğlu I, DePinto JV, Dolan DM, Evans MA, Farmer TM, Goto D, Han H, Höök TO, Knight R, Ludsin SA, Mason D, Michalak AM, Richards RP, Roberts JJ, Rucinski DK, Rutherford E, Schwab DJ, Sesterhehn TM, Zhang H, Zhou Y. 2014. Assessing and addressing the re-eutrophication of Lake Erie: central basin hypoxia. J Great Lakes Res 40:226-46.

Schmidtko S, Stramma L, Visbek M. 2017. Decline in global oceanic oxygen content during the past five decades. Nature 542:335-9.
Schön G, Geywitz S, Mertens F. 1993. Oxidation-reduction potential on phosphate phosphorus removal. Water Res 27:349-54

Shang EHH, Wu RSS. 2004. Aquatic hypoxia is a teratogen and affects fish embryonic development. Environ Sci Technol 38:4763-7.

Shiah FK, Ducklow HW. 1994. Temperature regulation of heterotrophic bacterioplankton abundance, production, and specific growth rate in Chesapeake Bay. Limnol Oceanogr 39:1243-58.

Smith L, Watzin MC, Druschel G. 2011. Relating sediment phosphorus mobility to seasonal and diel redox fluctuations at the sediment-water interface in a eutrophic freshwater lake. Limnol Oceanogr 56:2251-64.

Steinman A, Rediske R, Reddy KR. 2004. The reduction of internal phosphorus loading using alum in Spring Lake, Michigan. J Environ Qual 33:2040-8.

Steinman A, Ogdahl M. 2006. An analysis of internal phosphorus loading in White Lake. Scientific Technical Reports. ScholarWorks@GVSU. Paper 8.

Steinman AD, Ogdahl M, Rediske R, Ruetz CR, Biddanda BA, Nemeth L. 2008. Current Status and Trends in Muskegon Lake, Michigan. J Great Lakes Res 34:169-88.

Steinman A, Chu X, Ogdahl M. 2009. Spatial and temporal variability of internal and external phosphorus loads in Mona Lake, Michigan. Aquat Ecol 43:1-18.

Testa JM, Kemp WM. 2012. Hypoxia-induced shifts in nitrogen and phosphorous cycling in Chesapeake Bay. Limnol Oceanogr 57:835-50.

Vail J, Meyer A, Weinke A, Biddanda B. 2015. Water quality monitoring: lesson plan for exploring time-series data. J Michigan Teachers Assoc 6:37-48.

Vanderplancke G, Claireaux G, Quazuguel P, Madec L, Ferraresso S, Sévère A, Zambonino-Infante J, Mazurais D. 2015. Hypoxic episode during the larval period has long-term effects on European sea bass juveniles (Dicentrarchus labrax). Mar Biol $162: 367-76$.

Weinke AD, Kendall ST, Kroll DJ, Strickler EA, Weinert ME, Holcomb TM, Defore AA, Dila DK, Snider MJ, Gereaux LC, Biddanda BA. 2014. Systematically variable planktonic carbon metabolism along a land-to-lake gradient in a Great Lakes coastal zone. J Plankton Res 36:1528-42.

Wu RSS, Zhou BS, Randall DJ, Woo NYS, Lam PKS. 2003. Aquatic hypoxia is an endocrine disruptor and impairs fish reproduction. Environ Sci Technol 37:1137-41.

Zaikova E, Walsh DA, Stilwell CP, Mohn WW, Tortell PD, Hallam SJ. 2010. Microbial community dynamics in a seasonally anoxic fjord: Saanich Inlet, British Columbia. Environ Microbiol 12:172-91.

Zhang J, Gilbert D, Gooday AJ, Levin L, Naqvi SWA, Middelburg JJ, Scranton M, Ekau W, Peña A, Dewitte B, Oguz T, Montiero PMS, Urban E, Rabalais NN, Ittekkot V, Kemp WM, Ulloa O, Elmgren R, Escobar-Briones E, Van der Plas AK. 2010. Natural and human-induced hypoxia and consequences for coastal areas: synthesis and future development. Biogeosci 7:144367.

Zhou Y, Michalak AM, Beletsky D, Rao YR, Richards RP. 2015. Record-breaking Lake Erie hypoxia during 2012 drought. Environ Sci Technol 49:800-7. 